UDC 37.013 .42

DOI: $10.24045 / \mathrm{pp} .2017 .1 .18$

\title{
SOCIAL ADAPTATION OF TEENAGERS WITH DEVIANT BEHAVIOR THROUGH ART
}

O. A. Ovsyannikova

\author{
Candidate of Pedagogical Sciences \\ assistant professor \\ Tyumen State University \\ Tyumen, Russia
}

\begin{abstract}
The article substantiates the need for educational work with adolescents with behavioral problems; It reveals the relationship between the public, social problems and increasing of the number of adolescents with behavioral problems; analyses the notion of "social adjustment", a psychological portrait of teenagers with behavioral problems is considered; the mechanism of art influence on adolescents in the process of perception and creation of artistic and creative product; art acts in this case as a means of communication teenagers not only with peers but also with the author, the hero of various works of art; examples of creative tasks for photo and video therapy for teenagers.
\end{abstract}

Keywords: social adaptation; deviant behavior; adolescents; phototherapy; video therapy art.

The problem of deviant behavior in people's life and activity became more important in the last decades of a development of the Russian society. Years of crisis of social consciousness, economical and political reforms give growing numbers of deviant behavior. strengthening of social inequality of different groups of population, congestion parents, not clear perspectives of social protection of society, changes in value-motivational sphere, non-tolerance to representatives of other nationalities in modern society lead to increasing of number of teenagers and young people with different forms of deviant behavior. In its turn, teenage manifestations of deviant behavior entail various socio-economic and political issues affecting the stability of the Russian society. These processes are definitely connected.

In addition, we can observe the complexity in understanding and awareness of the growing person to belong to a culture, artistic and aesthetic values, resulting in disorientation, lack of core personal position, which is observed by teachers and psychologists loss of meaning, the desire to do something and make a difference. Teens are often unable to adapt socially, not always aware of their role in society. One of the ways to integrate into human society advocates an art that, according to L. S. Vygotsky, is showing a ... the most important center of all the biological and social processes of the individual in society," there is a "way of balancing the man with the world in the most critical and responsible moments of life" [2, c. 38]. Art as an evaluative criterion selects all "proper" and "not proper", which takes place in every person's life, offering its solutions, its output of any given situation, the development, has a paramount importance in the social adaptation of teenagers.

Despite the modernization of the current system of education in Russia, there are difficulties in solving the problems of social adaptation of teenagers in pedagogical process, which focuses more on learning rather than on education. There is a contradiction between the needs of society in thinking, creative, active, well-rounded personalities, on the one hand, and the narrowness of the edu- 
cational policy, expressed in the position of reducing the humanities, - on the other.

It is not enough to develop and support artistic disciplines, focusing on the development of student cognitive sphere, the educational system loses the emotional, creative component, which is impossible without the development of artistic and aesthetic orientation. This leads to the fact that in the majority of educational institutions studying becomes for school activities, forming a personality. Therefore, the social adaptation of teenagers in today's society seems significant problem that requires finding adequate ways and means to solve it, including by means of art.

Let's turn to the essence of the concept of "social adaptation". This term is considered by scientists in a variety of ways: as a process of human adaptation to the conditions of the social environment, and how the interaction of personality (social group) with the social environment [4]. We adhere to the view that social adaptation is, first of all, harmonization of relations of the subject (in this case, a teenager) and the social environment. An important aspect of social adaptation is the adoption of a teenager social role.

Let's consider the psychological portrait of teenagers with deviant behavior. An analysis of national literature which is focused on finding ways, means of minimizing, prevention and elimination of deviant behavior in society shows that the approaches to the identification and characterization of deviant behavior of the person is not fully reveal the essence of the phenomenon. Often used similar terminology - "deviant", "addictive", "destructive" behavior. But all these terms mean deviant behavior. Kolesnikova G. I. he notes that deviant adolescents is characterized by such features of emotional and volitional as increased anxiety, defective value system, especially in the field goals and the meaning of life. They tend to be impulsive, irritable, quick-tempered, aggressive, conflict, which hinders communication of adolescents with others and creates considerable difficulties in their upbringing. Sometimes teenagers commit unlawful acts [5]. This often by adolescent delinquency evaluated as an expression of independence and the manifestation of a kind of "heroism."

According E. B. Usova's opinion, difficult circumstances, improper family education, low educational and cultural level of the surrounding influence on many, but not all the conditions set out in these children and adolescents are deviant personalities [9]. Deviant behavior of adolescents is formed together external and internal factors, not the least of which is the predisposition of the individual to the internal adoption of their deviant behavior, that, first of all, depends on the psychological characteristics of the minor.

The opposite concept of deviant behavior is a behavioral norm, which includes and creativity (as Erich Fromm) [10]. One form of such behavior, in the opinion of V. S. Rothenberg, V. V. Arshavsky, search activity is aimed at meeting the need for new information, new experiences, expanding their experience [8]. The paradox is that the deviant and creative behavior can be worn by the similarities. The difference also lies in the fact that for genuine creativity (ideal norm) pleasure of the search process itself, while the main goal is the result of deviant variety of search activity - fun. J. Godefroy notes that creative thinking is characteristic for an ideal behavior, has its own peculiarities: it is plastic, mobile and original [3].

T. V. Buinevich allocates 5 groups of causes of deviant behavior among adolescents, only one (the first one) involves the treatment of a psychiatrist and medical and psychological effects, work with other groups of adolescents provides a set of specially organized psychological and pedagogical activities, including specially organized process of education [1].

The cause of deviant behavior in one group of teenagers - various deviations in the

Paradigmata poznńní. I. 20 I 
development of emotional and volitional, characterological features, reaching its degree of accentuation and psychopathy. The cause of deviant behavior in the 2 nd group of teens associated with aborted moral ideas, inability to control their behavior with the help of internal standards. The cause of deviant behavior in group 3: typical teenage response to abnormal behavior of adults, parents and teachers. 4 In a group of teenagers cause of their deviant behavior is related to the specific features of self-awareness and consciousness. They have their own system of values, norms, rules, not always coinciding with adult values. The cause of deviant behavior in the adolescent group, 5 in one of the natural forms of behavior in this age group - in self needs, group behavior, aggressive experimentation.

Representatives of the psychological and pedagogical direction of approach to the problems of deviant behavior among adolescents and young people (I. Yu. Levchenko, S. D. Zabramnaya, T. G. Vizel) engaged in the creation of special training, educational and correctional environment in educational institutions $[7 ; 11]$. One of the most effective means of working with teacher deviant behavior of adolescents may be a variety of types and forms of art therapy, which is considered to be the progenitor of the Austrian painter E. Kramer [6].

Various forms of art allow teenagers to communicate not only with their peers in creating artistic and creative product (drawings, photographs, musical composition, etc.), but also with the author and the hero of the work of art through the inner speech through the comprehension of the content of the perceived works of art. It brought the ability to perceive reality aesthetically and in life and in art. Inclusion in the various activities related to art (art-voice, music, theater, fine) ensure the free expression and selfknowledge of teenagers, direct their creative energy in a positive direction. In these positions is a mechanism arts influence on the personality of adolescents.

Correction possibilities of art in relation to young people are also connected with the fact that it is a source of new positive experiences, gives rise to new creative needs and ways to meet them. And improving the aesthetic needs of adolescents, and to activate their potential in art, practice and creativity this is the implementation of social and educational function of art.

Various forms and methods of art therapy help teenagers to cope with a variety of adverse conditions: anxiety, fear, aggression, negative behavior, emotional experience of rejection, provide an opportunity to overcome and resolve conflicts with their own "I" and others. There are various areas of art therapy: paint therapy, music therapy, dance therapy, bibliotherapy, drama therapy, movie therapy, doll therapy, imago therapy, sand therapy, etc. Let us consider two kinds of art therapy - video therapy and phototherapy, which, in our opinion, meet the passage of time, the interests of the adolescent children, and most importantly, contribute to the harmonization of their relationship with the social environment, which is defined by the term "social adaptation". Generally under video therapy, therapy or feature films author meant ancillary equipment based on viewing and discussing the film, in which the story and emotional impact are correlated with certain teenage problem. But we consider video therapy as an opportunity to create their own video teenagers movies, PSAs.

Phototherapy as a way to create a photo opens the method to self-knowledge, solving psychological problems of adolescents. Almost every photo which is taken by a teenager or by other people, causes certain thoughts, associations and emotions. There are such phototherapy technologies as a slide therapy, gallery of images, photos, etc. It can 
be used as a reflection of the different situations in life. Let us to consider some possible tasks for teens in these areas of art therapy.

1. Task for phototherapy. Teens are invited to create a slideshow of your own photos or pictures found on the internet on "Beauty in life and in art." Create a slide show should be submitted to their peers and to explain why they chose these photos. We obtain a kind of photo essay, which allows to realize a teenager and his peers philosophical meaning of "beauty".

2. Task for video therapy. Teens are invited to create a social video clip on the topic «Help». Their task is to see and capture the life of the city on the plots of the need for assistance to people, animals, their peers and others. The establishment of such a video clip allows you to awaken teenagers active social position, they learn to pay attention to the people who need help. The main thing they are able to meet their creative needs for self-expression in the positive sense of the word.

Conclusion. Art, as a factor in the development of art, has an effect on the emotional sphere of personality. Participation of teenager in artistic activity expands its social experience teaches adequate interaction and communication, provides for prevention, correction of violations of communicative sphere and deviant behavior. Art-therapy sessions to help young people to express their thoughts, feelings, moods in the creative process, contribute to the social significance of the statement of identity.

\section{Bibliography}

1. Буйневич Т. В. Психопрофилактическая и психокоррекционная работа с учащимися девиантного поведения. - Минск, 2006.

2. Выготский Л. С. Психология искусства. - М. : Искусство, 1968.

3. Годфруа Ж. Что такое психология: в 2-х т. / пер. с франц Т. 1. - М. : Мир, 1992.

4. Еникеев М. И. Энциклопедия. Общая и социальная психология. - М. : Нова, 2002.
5. Колесникова Г. И. Основы психопрофилактики и психокоррекции. - Ростов/н/Д: Феникс, 2005.

6. Крамер Е. Арт-терапия с детьми. - Генезис. 2013.

7. Левченко И. Ю., Забрамная С. Д., Добровольская Т. А. и др. Психолого-педагогическая диагностика : учеб. пособие для студ. высш. пед. учеб. заведений. - М. : Издательский центр «Академия», 2003.

8. Ротенберг В. С., Аршавский В. В. Поисковая активность и адаптация. - М. : Наука, 1984.

9. Усова Е. Б. Психология девиантного поведения. - Минск, 2010.

10. Fromm, E. Man for Himself: An Inquiry Into the Psychology of Ethics (1947) / пер. Е. М. Спировой. - М. : Аст, 2010.

11. Визель Т. Г., Сенкевич Л. В., Янышева В. А., Железнова А. К. Девиантное поведение подростков: теория и эксперименты (монография). - Тула, 2007.

\section{Bibliography}

1. Bujnevich T. V. Psihoprofilakticheskaja i psihokorrekcionnaja rabota $\mathrm{s}$ uchashhimisja deviantnogo povedenija. - Minsk, 2006.

2. Vygotskij L. S. Psihologija iskusstva. - M. : Iskusstvo, 1968.

3. Godfrua Zh. Chto takoe psihologija: v 2-h t. / per. s franc T. 1. - M. : Mir, 1992.

4. Enikeev M. I. Jenciklopedija. Obshhaja i social'naja psihologija. - M. : Nova, 2002.

5. Kolesnikova G. I. Osnovy psihoprofilaktiki i psihokorrekcii. - Rostov/n/D: Feniks, 2005.

6. Kramer E. Art-terapija s det'mi. - Genezis. 2013.

7. Levchenko I. Ju., Zabramnaja S. D., Dobrovol'skaja T. A. i dr. Psihologo-pedagogicheskaja diagnostika : ucheb. posobie dlja stud. vyssh. ped. ucheb. zavedenij. - M. : Izdatel'skij centr «Akademija», 2003.

8. Rotenberg V. S., Arshavskij V. V. Poiskovaja aktivnost' i adaptacija. - M. : Nauka, 1984.

9. Usova E. B. Psihologija deviantnogo povedenija. - Minsk, 2010

10. Fromm, E. Man for Himself: An Inquiry Into the Psychology of Ethics (1947) / per. E. M. Spirovoj. - M. : Ast, 2010.

11. Vizel' T. G., Senkevich L. V., Janysheva V. A., Zheleznova A. K. Deviantnoe povedenie podrostkov: teorija i jeksperimenty (monografija). Tula, 2007.

(C) Ovsyannikova O. A., 2017. 